\title{
ZMIANY STRUKTURY EKONOMICZNEJ GOSPODARSTW ROLNYCH W POLSCE - OCENA OPÓŹNIEŃ W ROZWOJU STRUKTURALNYM
}

\author{
Anna Rzeszutko \\ Katedra Ekonomii i Polityki Gospodarczej w Agrobiznesie \\ Uniwersytetu Przyrodniczego w Poznaniu \\ Kierownik Katedry: prof. dr hab. Walenty Poczta
}

\begin{abstract}
Słowa kluczowe: opóźnienia strukturalne, przemiany strukturalne, rolnictwo, struktura ekonomiczna, województwa, regionalna analiza strukturalna

Key words: structural development gap, structural changes, agriculture, economic structure of farms, voivodeships, regional structural analysis

S y n o p s i s. Celem artykułu była próba oceny opóźnień w rozwoju strukturalnym rolnictwa w Polsce w układzie regionalnym wraz z oceną procesów upodabniania się struktury ekonomicznej gospodarstw rolnych. Strukturę tę wyznaczono na podstawie wartości standardowej produkcji (SO). Badania przeprowadzono dla okresu 2005-2013 na podstawie danych Eurostatu. Do oceny opóźnień posłużono się procedurą proponowaną przez K. Kukułę z wykorzystaniem metod statystycznej regionalnej analizy strukturalnej. Procedura ta wymagała wskazania struktury wzorcowej (województwa-wzorca), którą wyznaczono z wykorzystaniem syntetycznego miernika poziomu rozwoju Hellwiga. Przeprowadzone badania wskazują, iż największymi opóźnieniami w rozwoju strukturalnym charakteryzowały się województwa w południowo-wschodniej Polsce. Jednocześnie w województwach tych dystans strukturalny w stosunku do województwa-wzorca (woj. wielkopolskiego) zwiększył się w badanym okresie.
\end{abstract}

\section{WPROWADZENIE}

W badaniach społeczno-ekonomicznych zagadnienia dotyczące zróżnicowania $\mathrm{w}$ poziomie rozwoju i opóźnień rozwojowych są często podejmowanym tematem. Mogą dotyczyć zarówno gospodarek jako całości, jak i ich poszczególnych segmentów. Ponadto mogą się odnosić do różnych jednostek terytorialnych.

Postrzeganie rozwoju jako procesu zmian ilościowych (wzrostu danych wielkości ekonomicznych) połączonych ze zmianami jakościowymi (strukturalnymi) umożliwia badanie procesów rozwojowych przez pryzmat przemian strukturalnych. Wynika to z faktu, iż przemiany strukturalne traktowane są jako wynik - efekt procesów rozwoju, choć często wskazuje się także, że są jego czynnikiem [Ezeala-Harrison 1996, Kukuła 1996, Małuszyńska 1993, Onufer 2009].

W ramach badań nad zmianami strukturalnymi, obok zmian relacji dotyczących struktury wytwarzania, podziału dochodu narodowego bądź efektywności wykorzystania 
zasobów czynników produkcji, można wyróżnić także przekształcenia strukturalne dokonujące się wewnątrz każdego z segmentów gospodarki, w tym w rolnictwie [Rzeszutko 2014a]. Powszechnie ekonomiści rolni uważają, że zmiany struktur i form gospodarowania w sektorze rolnym, przy wzroście produkcji, są równoznaczne z jego rozwojem [Kowalczyk 1991, Kulawik 1997, Woś 2004].

Renata Przygodzka wskazała na trzy aspekty przekształceń strukturalnych w rolnictwie - sektorowy, regionalny i wewnątrzrolniczy. Aspekt sektorowy określa m.in. rolę (udział) rolnictwa w wytwarzaniu PKB bądź zatrudnieniu siły roboczej. Aspekt regionalny powiązany jest głównie ze zróżnicowaniem przestrzennym poziomów rozwoju rolnictwa i dążeniem do zmniejszenia znacznych dysproporcji regionalnych w tym zakresie. Natomiast aspekt wewnątrzrolniczy dotyczy zmian $w$ ramach struktury $i$ powiązań wszystkich podsystemów samej gospodarki rolnej [Przygodzka 2011, s. 145].

Choć z reguły struktura rolnictwa utożsamiana jest głównie ze strukturą obszarową, to jednak współcześnie coraz większą wagę przywiązuje się do siły produkcyjno-ekonomicznej gospodarstw rolnych determinowanej zasobami i relacjami czynników produkcji, kierunkiem i skalą produkcji czy osiąganymi wynikami [Przygodzka 2011, Rzeszutko 2014a, Zegar 2009].

Badania przemian strukturalnych w sektorze rolnym w Polsce są niezwykle istotne $\mathrm{z}$ uwagi na znaczne opóźnienia rozwojowe względem konkurentów - gospodarstw rolnych z krajów UE ${ }^{1}$ [Karwat-Woźniak 2016, Pawlak 2014, Poczta i in. 2013], a znaczne zróżnicowanie w poziomie rozwoju rolnictwa w skali kraju wskazuje także na konieczność przyjrzenia się tym przemianom w układzie regionalnym [Bański 2007, Bożek 2012, Głębocki 2014, Rzeszutko 2014a, 2014b, 2016, Sikorska i in. 2009].

Nie bez znaczenia są też znaczne środki pieniężne przeznaczane w ramach wspólnej polityki rolnej na politykę strukturalną w rolnictwie w Polsce w kolejnych perspektywach finansowych [Czyżewski, Stępień 2014]. Jerzy Wilkin podkreślał, że współcześnie w zasadzie w każdym kraju o gospodarce rynkowej procesy rozwoju w rolnictwie wspierane są polityką państwa (ugrupowania integracyjnego), a jej rola jest szczególnie duża w krajach wysoko rozwiniętych, w których instrumentarium tej polityki jest bardzo rozbudowane. Celem tej polityki staje się wspieranie pożądanych przemian strukturalnych i zmniejszanie dysproporcji rozwojowych (między regionami) [Wilkin 2012].

Celem artykułu jest próba oceny opóźnień w rozwoju strukturalnym rolnictwa w Polsce w układzie regionalnym wraz z oceną procesów upodabniania się struktur. Zastosowana procedura badawcza pozwala skwantyfikować czasookres dzielący stadium rozwoju badanego obiektu względem obiektu-wzorca (przodującego w danej dziedzinie), w związku z czym stanowi obiektywne uzupełnienie szacunków ekspertów, które zazwyczaj mają charakter subiektywny [Kukuła 2010]. Jednocześnie pozwala wskazać, czy zachodzące procesy prowadzą do zmniejszania, czy do zwiększania dysproporcji rozwojowych.

\section{METODYKA I ŹRÓDŁA DANYCH}

Oceny opóźnień w rozwoju strukturalnym rolnictwa w Polsce dokonano metodami regionalnej analizy strukturalnej. Zastosowano procedurę zaproponowaną przez Karola Kukułę [Kukuła 1996, 2010]. Ocenie poddano strukturę ekonomiczną gospodarstw rolnych

Liczne opracowania naukowe wskazują m.in. na takie wadliwości, jak: nadmiar zasobów pracy, duże rozdrobnienie gospodarstw rolnych, niski potencjał inwestycyjny, brak specjalizacji produkcji czy względnie niska, choć rosnąca konkurencyjność międzynarodowa. 
Tabela 1. Grupowanie gospodarstw rolnych według wielkości ekonomicznej (euro)

\begin{tabular}{lr}
\hline Nazwa grupy & Rozmiar w euro \\
\hline \multirow{2}{*}{ Bardzo małe } & $<2000$ \\
& $2000-3999$ \\
$4000-7999$ \\
\hline \multirow{2}{*}{ Małe } & $8000-14999$ \\
& $15000-24999$ \\
\hline Średnio małe & $25000-49999$ \\
\hline Średnio duże & $50000-99999$ \\
\hline \multirow{2}{*}{ Duże } & $100000-249999$ \\
\hline Bardzo duże & $250000-499999$ \\
\hline
\end{tabular}

Źródło: opracowanie własne na podstawie [Goraj i in. 2011]. wyznaczoną na podstawie ich wielkości ekonomicznej - wartości standardowej produkcji (SO - ang. Standard Output $)^{2}$. Gospodarstwa rolne podzielono według klas wielkości ekonomicznej: bardzo małe, małe, średnio małe, średnio duże, duże oraz bardzo duże, co szczegółowo zestawiono w tabeli 1.

Ocena opóźnień w rozwoju strukturalnym (ocena dystansu czasowego) dla poszczególnych województw w Polsce wymagała przyjęcia obiektu wzorcowego. W opracowaniu województwo-wzorzec wyznaczono na podstawie syntetycznego miernika rozwoju Hellwiga przedstawiającego poziom rozwoju rolnictwa. Procedura wyznaczania wartości miernika przebiegała w następujących etapach [Wysocki 2010]:

Etap 1. Wybór cech prostych na podstawie przesłanek merytorycznych i statystycznych (w tym poziom zmienności cech prostych umożliwiający wykluczenie zmiennych o niskiej wartości informacyjnej, analiza elementów diagonalnych macierzy odwrotnej do macierzy korelacji R, która pozwala wyeliminować cechy nadmiernie skorelowane).

Wykorzystano następujące cechy proste:

- przeciętna powierzchnia użytków rolnych w gospodarstwie (ha),

- udział UR w gospodarstwach o powierzchni powyżej 30 ha UR (\%),

- powierzchnia UR na jednostkę pracy (ha/AWU),

- nakłady kapitału trwałego na jednostkę powierzchni (euro/ha),

- nakłady kapitału obrotowego na jednostkę powierzchni (euro/ha),

- nakłady kapitału trwałego na jednostkę pracy (euro/AWU),

- wartość dodana brutto na gospodarstwo (tys. euro).

Wartości cech prostych wykorzystano w macierzy danych, która była podstawą konstrukcji miernika syntetycznego:

$$
X=\left[\begin{array}{cccc}
x_{11} & x_{21} & \ldots & x_{1 m} \\
x_{12} & x_{22} & \ldots & x_{2 m} \\
\ldots & \ldots & \ldots & \ldots \\
x_{n 1} & x_{n 2} & \ldots & x_{n m}
\end{array}\right]
$$

gdzie: $x_{i j}(i=1,2, \ldots, n, j=1,2, \ldots, m)$ przedstawia wartość $j$-tej cechy prostej $\mathrm{w}$ jednostce statystycznej o numerze $i$.

Etap 2. Normalizacja wskazanych cech prostych, która umożliwia ujednolicenie ich charakteru i sprowadzenie ich wartości do porównywalności. Wszystkie cechy określono jako stymulanty - dodatnio skorelowane z miernikiem syntetycznym, w związku z czym podczas normalizacji zastosowano następującą formułę:

2 Jest to średnia (z 5 lat) wartość produkcji danej działalności rolniczej uzyskanej z 1 ha lub od 1 zwierzęcia w ciągu 1 roku w przeciętnych warunkach produkcyjnych w danym regionie. 


$$
z_{i j}=\frac{x_{i j}-\min \left\{x_{i j}\right\}}{\max _{i}\left\{x_{i j}\right\}-\min _{i}\left\{x_{i j}\right\}}
$$

Etap 3. Wyznaczenie wartości syntetycznego miernika rozwoju Hellwiga $\left(\widetilde{q}_{i}\right)$ (wzór 2.) poprzez obliczenie odległości euklidesowych od wzorca rozwoju na podstawie znormalizowanych wartości cech prostych $\left(z_{i j}\right)$ z wykorzystaniem wzoru [Wysocki 2010]:

$$
\widetilde{q}_{i}=1-\frac{q_{i}^{(2)}}{q_{0}}
$$

gdzie:

$$
q_{i}^{(2)}=\sqrt{\frac{\sum_{j=1}^{m}\left(z_{i j}-z_{0 j}\right)^{2}}{m}},(i=1,2, \ldots, n),
$$

a $Z_{0 j}$ jest znormalizowaną wartością $j$-tej cechy dla jednostki wzorcowej, przedstawionej w postaci wektora $z=\left(z_{01}, z_{02}, \ldots, z_{0 m}\right)$ :

$$
q_{0}=\bar{q}_{0}+2 s_{0}
$$

gdzie:

$$
\begin{aligned}
& \bar{q}_{0}=\frac{\sum_{i=1}^{n} q_{i}^{(2)}}{n} \\
& s_{0}=\sqrt{\frac{\sum_{i=1}^{n}\left(q_{i}^{(2)}-\bar{q}_{0}\right)^{2}}{n}}
\end{aligned}
$$

Obliczony w ten sposób miernik syntetyczny przyjmuje wartości z przedziału [0,1], przy czym wartości bliższe jedności świadczą o wyższym poziomie rozwoju rolnictwa [Wysocki 2010]. Za województwo-wzorzec przyjęto województwo, dla którego wartość syntetycznego miernik poziomu rozwoju Hellwiga była największa.

Etap 4. Podział badanej zbiorowości (województw) na cztery grupy o różnym poziomie rozwoju rolnictwa:

grupa I: $\widetilde{q}_{i} \geq \bar{q}+s_{q}$

grupa II: $\bar{q}+s_{q}>\widetilde{q}_{i} \geq \bar{q}$

grupa III: $\bar{q}>\widetilde{q}_{i} \geq \bar{q}-s_{q}$

grupa IV: $\widetilde{q}_{i}<\bar{q}-s_{q}$ gdzie: $\bar{q}-$ średnia arytmetyczna, $s_{q}$ - odchylenie standardowe.

Grupa I charakteryzuje się najwyższym, natomiast grupa IV najniższym poziomem badanego zjawiska. 
Po wyznaczeniu województwa-wzorca przystąpiono do procedury oceny upodobniania się struktur oraz oceny opóźnień w rozwoju strukturalnym w pozostałych województwach, na którą składały się następujące etapy [Kukuła 2010]:

Etap 1. Wyznaczenie ciągów miar stopnia intensywności zmian strukturalnych w poszczególnych województwach (wzór 7.) w badanym czasie na podstawie miary zróżnicowania struktury w ujęciu dynamicznym o postaci ${ }^{3}$ :

$$
v_{\mathrm{t}+\mathrm{n}, \mathrm{t}}=\frac{\sum_{i=1}^{k}\left|\alpha_{i t+n}-\alpha_{i t}\right|}{2}
$$

(wzór 7.)

gdzie: $k$ - liczba przedziałów wielkości ekonomicznej, $\alpha_{i t+n}-$ udział liczby gospodarstw W danym przedziale wielkości ekonomicznej w badanym województwie w okresie $t+n$, $\alpha_{i t}$ - udział liczby gospodarstw w danym przedziale wielkości ekonomicznej w badanym województwie w okresie $t$.

Miara ta przyjmuje wartości z przedziału [0,1], przy czym większe wartości oznaczają większą intensywność zmian badanej struktury (lub większe zróżnicowanie w stosunku do początku badanego okresu).

Etap 2. Wyznaczenie przeciętnej prędkości (przeciętnego stopnia) zmian strukturalnych (wzór 8) dla poszczególnych województw (dla województwa-wzorca, dla pozostałych województw):

$$
v=\frac{\sum_{t=1}^{n} \sum_{i=1}^{k}\left|\alpha_{i t}-\alpha_{i(t-1)}\right|}{2 n}
$$

(wzór 8.)

gdzie: $k$ - liczba przedziałów wielkości ekonomicznej, $\alpha_{i t}-$ udział liczby gospodarstw w danym przedziale wielkości ekonomicznej w badanym województwie w okresie t, $\alpha_{i(t-1)}$ udział liczby gospodarstw w danym przedziale wielkości ekonomicznej w badanym województwie w okresie $t$ - 1 .

Miara ta stanowi średnią wartość łańcuchowych miar stopnia intensywności zmian badanej struktury w danej jednostce (województwie) z okresu na okres. Wzrost przeciętnej wartości stopnia zmian, która zawiera się w przedziale [0,1], przyspiesza tempo procesu przekształceń i upodabniania się danej struktury do wzorca.

Etap 3. Ustalenie stopnia monotoniczności zmian badanych struktur ( $)$ ) (struktury województwa-wzorca $\eta_{\mathrm{A}}$ oraz struktury pozostałych województw $\eta_{\mathrm{B}}$ ) na podstawie wzoru 9. Stopień ten pozwala ocenić, czy ewolucja zmian utrzymuje względnie stały kierunek.

$$
\eta_{n}=\frac{v_{n, 0}}{\sum_{t=1}^{n} v_{t, t-1}}
$$

(wzór 9.)

gdzie: $v_{n, 0}$-stopień intensywności zmian strukturalnych danej struktury pomiędzy skrajnymi momentami czasowymi badanego okresu, $v_{t, t-1}$ - stopień intensywności zmian strukturalnych danej struktury w okresie $t, t-1$.

Wyższy stopień monotoniczności struktury (dążący do 1) oddziałuje dodatnio na okres „dojścia” struktury danego obiektu do struktury obiektu-wzorca.

Etap 4. Wyznaczenie współczynnika zakłóceń zmian badanej struktury $(z)$ dla poszczególnych województw (dążących do struktury województwa-wzorca) (wzór 10):

3 W literaturze miernik ten przyjmuje także inne nazwy: wskaźnik inferencyjnych zmian strukturalnych [Małuszyńska 1993], syntetyczny miernik zmian strukturalnych [Kowalczyk 1991]. 


$$
\mathrm{z}=\frac{1}{\eta_{n B}}
$$

gdzie: $\eta_{n B}$ - stopień monotoniczności zmian struktury badanych województw (kolejno wszystkich, poza województwem wzorcem - wielkopolskim).

Uwzględnienie współczynnika zakłóceń zmian badanej struktury wynika z możliwości pojawienia się niemonotonicznych zmian tej struktury.

Etap 5. Ustalenie odległości (d) (dystansu strukturalnego) pomiędzy strukturą województwa-wzorca a strukturami pozostałych województw w ostatnim z obserwowanych okresów:

$$
d_{A B}=\frac{\sum_{i=1}^{k}\left|\alpha_{A}-\alpha_{B}\right|}{2}
$$

(wzór 11.)

gdzie: $\alpha_{A}-$ udział liczby gospodarstw w danym przedziale wielkości ekonomicznej w województwie-wzorcu w danym okresie, $\alpha_{B}$ - udział liczby gospodarstw w danym przedziale wielkości ekonomicznej w województwie dążącym do wzorca w danym okresie.

Do wyznaczenia odległości wykorzystywana jest miara zróżnicowania pomiędzy strukturami, przyjmująca ponownie wartości z przedziału $[0,1]$. Im wartości te są większe, tym odległość dzieląca struktury wzrasta. Chociaż do wyznaczenia przybliżonego czasu (dystansu czasowego) dzielącego badane struktury od struktury województwa-wzorca wymagane jest ustalenie odległości w ostatnim momencie badanego okresu, to ustalenie tej odległości również na początku badanego okresu pozwala zaobserwować tendencje zachodzących zmian - jej zwiększanie lub skracanie.

Etap 6. Określenie przybliżonego czasu ( $l$ ) (dystansu czasowego - liczby lat) niezbędnego do upodobnienia się struktury województwa „opóźnionego” do struktury województwa-wzorca z ostatniego roku obserwacji (wzór 12.):

$$
l=\frac{z * d_{A B}}{v_{B}}
$$

(wzór 12.)

gdzie: $z$ - współczynnik zakłóceń, $d_{A B}$ - dystans strukturalny pomiędzy strukturą województwa-wzorca a strukturami pozostałych województw w ostatnim z obserwowanych okresów (2013), $v_{B}$ - przeciętna zmian struktur poszczególnych województw (poza województwem-wzorcem).

Do badań wykorzystano dane Eurostatu. Zakres czasowy badań objął lata 2005-2013, przy czym dane pochodzą z lat 2005, 2007, 2010 i 2013, co było podyktowane dostępnością danych.

\section{WYNIKI BADAŃ - WYZNACZENIE STRUKTURY WZORCOWEJ}

Zastosowanie syntetycznego miernika rozwoju Hellwiga pozwoliło na przyporządkowanie województw do poszczególnych grup różniących się poziomem rozwoju rolnictwa oraz wskazanie województwa o najwyższym poziomie jego rozwoju. Województwem tym było wielkopolskie (WP), które wraz z opolskim (OP) tworzyło pierwszą grupę - o wysokim poziomie rozwoju gospodarstw rolnych. W skład grupy drugiej, w której poziom rozwoju określono jako średni, weszły następujące województwa: zachodniopomorskie (ZP), warmińsko-mazurskie (WM), kujawsko-pomorskie (KP), lubuskie (LS), 


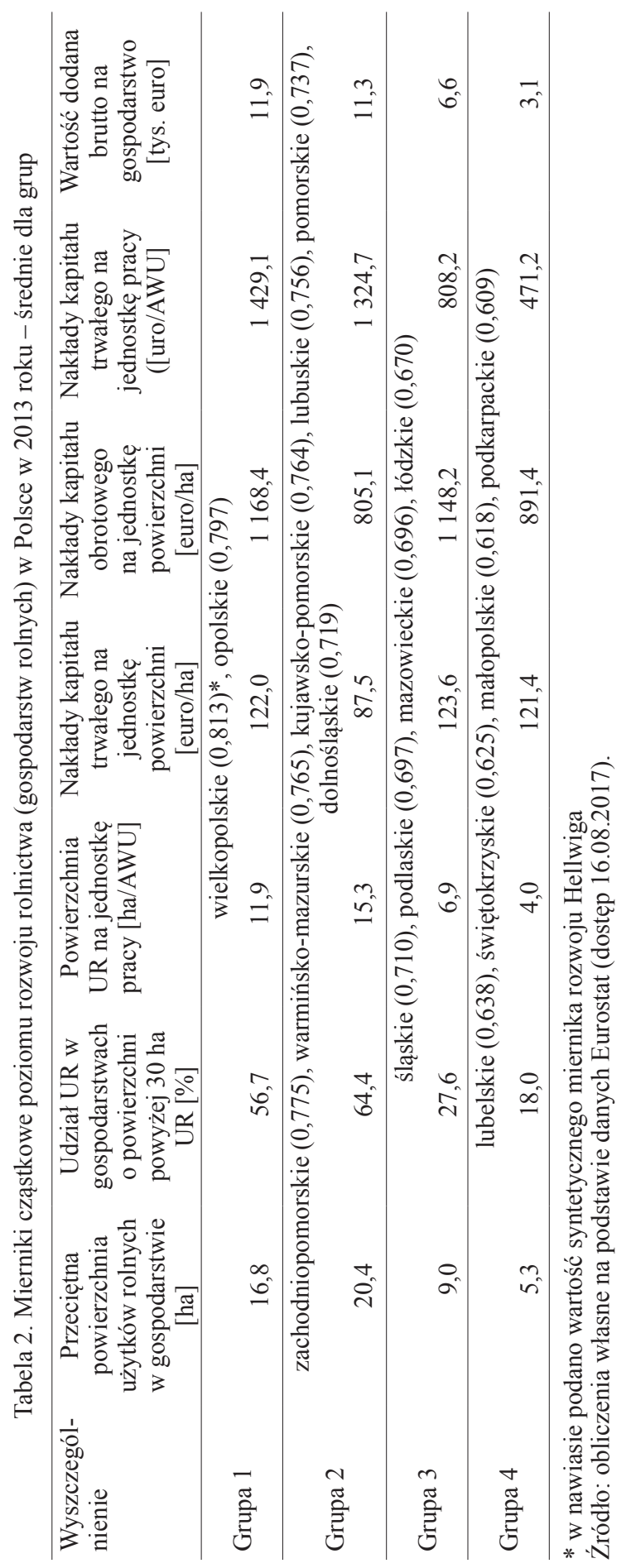

pomorskie (PM) i dolnośląskie (DS.). Grupę trzecią, o niskim poziomie rozwoju rolnictwa tworzyły województwa: śląskie (ŚL), podlaskie (PD), mazowieckie (MZ) oraz łódzkie (LD). W ostatniej - czwartej grupie znalazły się z kolei województwa lubelskie (LB), świętokrzyskie (ŚW), małopolskie (MP) i podkarpackie (PK). Charakteryzowały się one relatywnie najniższym poziomem rozwoju (tab. 2.). Z uwagi na cel opracowania i jego ograniczoną objętość wyodrębnione grupy województw nie zostaną szczegółowo scharakteryzowane. Średnie wartości cech prostych zostały zawarte w tabeli 2 .

\section{OCENA EWOLUCJI STRUKTUR EKONOMICZNYCH GOSPODARSTW ROLNYCH}

Przed próbą szacowania dystansu czasowego dzielącego strukturę ekonomiczną w poszczególnych województwach w stosunku do województwa-wzorca należy wspomnieć o zmianach, które zaszły w liczebności i strukturze gospodarstw rolnych według ich wielkości ekonomicznej [por. Rzeszutko 2014, Rzeszutko 2016].

W badanym okresie (20052013) liczba gospodarstw rolnych w Polsce uległa wyraźnemu zmniejszeniu. Wynika to m.in. z faktu, iż od 2010 roku w statystykach nie uwzględnia się już gospodarstw najmniejszych obszarowo (z reguły poniżej 1 ha UR), które łącznie użytkują 2\% lub mniej powierzchni użytków 
rolnych lub też łącznie utrzymują 2\% lub mniej ogólnego pogłowia zwierząt gospodarskich ${ }^{4}$. $Z$ reguły gospodarstwa te zaliczały się do grupy gospodarstw z najmniejszych przedziałów wielkości ekonomicznej - gospodarstw bardzo małych [Farm... 2012], stąd zmiany w liczebności tych gospodarstw w stosunku do 2005 roku są tak duże (tab. 3.).

Przy ogólnym krajowym zmniejszeniu liczebności gospodarstw prowadzących działalność rolniczą (z 2,5 mln w 2005 r. do 1,4 mln w 2013 r.) $)^{5}$ niemal w każdym województwie obserwowano tendencję zmniejszania się liczby gospodarstw określanych przez FADN jako bardzo małe i małe (z przedziałów wielkości ekonomicznej do 24,9 tys. euro) i zwiększania się liczby gospodarstw rolnych powyżej tej wielkości (tab. 3. ${ }^{6}$. Kierunek obserwowanych zjawisk ma charakter pozytywny, gdyż wzrasta liczba gospodarstw zdolnych do rozwoju i odtwarzania potencjału produkcyjnego [Michna 2011].

Nadal jednak zróżnicowanie regionalne w zakresie struktury ekonomicznej gospodarstw rolnych w Polsce jest bardzo duże. W południowo-wschodnich województwach wciąż dominują gospodarstwa bardzo małe i małe (do 24,9 tys. euro SO), których udział wynosi od ponad 93\% w śląskim do prawie 98\% w podkarpackim. Tymczasem w województwach północnej Polski (warmińsko-mazurskie, podlaskie) i centralno-zachodniej (wielkopolskie, kujawsko-pomorskie) udziały te wynoszą między 72 a 76\% (tab. 3.).

Zmiana kryterium kwalifikowania gospodarstw rolnych do badanej zbiorowości, choć nieco ograniczyła, to jednak nie uniemożliwiła wnioskowania w zakresie zmian struktury ekonomicznej gospodarstw rolnych i oceny opóźnień w rozwoju strukturalnym, ponieważ we wszystkich badanych jednostkach (województwach) zastosowano takie samo kryterium.

W badanym okresie najwyższą średnią prędkość zmian struktury ekonomicznej gospodarstw rolnych odnotowano w województwach: opolskim $(0,0902)$, zachodniopomorskim $(0,0776)$, warmińsko-mazurskim $(0,0769)$, kujawsko-pomorskim $(0,0754)$ oraz pomorskim $(0,0697)$, a więc w tych, które charakteryzują się wysokim bądź średnim poziomem rozwoju (tab. 4., 2.). Wysoka wartość przeciętnej prędkości zmian struktur oddziałuje na tempo procesu ich upodabniania się do struktury wzorcowej i pozytywnie wpływa na okres „dojścia” do tej struktury [Kukuła 1996].

Skutkiem relatywnie dużego średniego tempa zmian było względnie duże zróżnicowanie ich struktur w 2013 roku względem własnej struktury w 2005 roku. W wymienionych województwach wskaźniki zróżnicowania struktur były bowiem największe spośród wszystkich województw (tab. 4.).

Jednocześnie najmniejszą przeciętną prędkość zmian odnotowano głównie w województwach o najniższym poziomie rozwoju rolnictwa: podkarpackim $(0,0201)$, małopolskim $(0,0346)$, świętokrzyskim $(0,0417)$ oraz śląskim $(0,0463)$. W tych województwach zróżnicowanie struktury ekonomicznej gospodarstw rolnych w 2013 roku w stosunku do okresu wyjściowego było najmniejsze (tab. 4.).

Analiza łańcuchowych miar stopnia intensywności zmian strukturalnych w badanym okresie we wszystkich województwach wykazała, że najwyższa wartość została osiągnięta w roku 2010 w stosunku do 2007, co związane było ze wspomnianą już zmianą kryteriów

$4 \quad$ Rozporzadzenie Parlamentu Europejskiego i Rady (WE) Nr 1166/2008 z dnia 19 listopada 2008 r. [OJ L 321, z 1.12.2008] wprowadziło zmiany progu wielkości gospodarstwa (na podstawie wielkości obszarowej bądź stada zwierząt).

5 Gdyby kryteria wynikające z rozporządzenia Parlamentu Europejskiego i Rady (WE) Nr 1166/2008 zastosować dla gospodarstw w 2005 roku, wówczas według Eurostatu ich liczba wyniosłaby nie 2,5, a niecałe 1,9 mln.

6 Wyjątek stanowią województwa lubelskie, małopolskie, podkarpackie i świętokrzyskie, w których spadek liczebności dotyczy gospodarstw bardzo małych - do 7,9 tys. euro SO. 


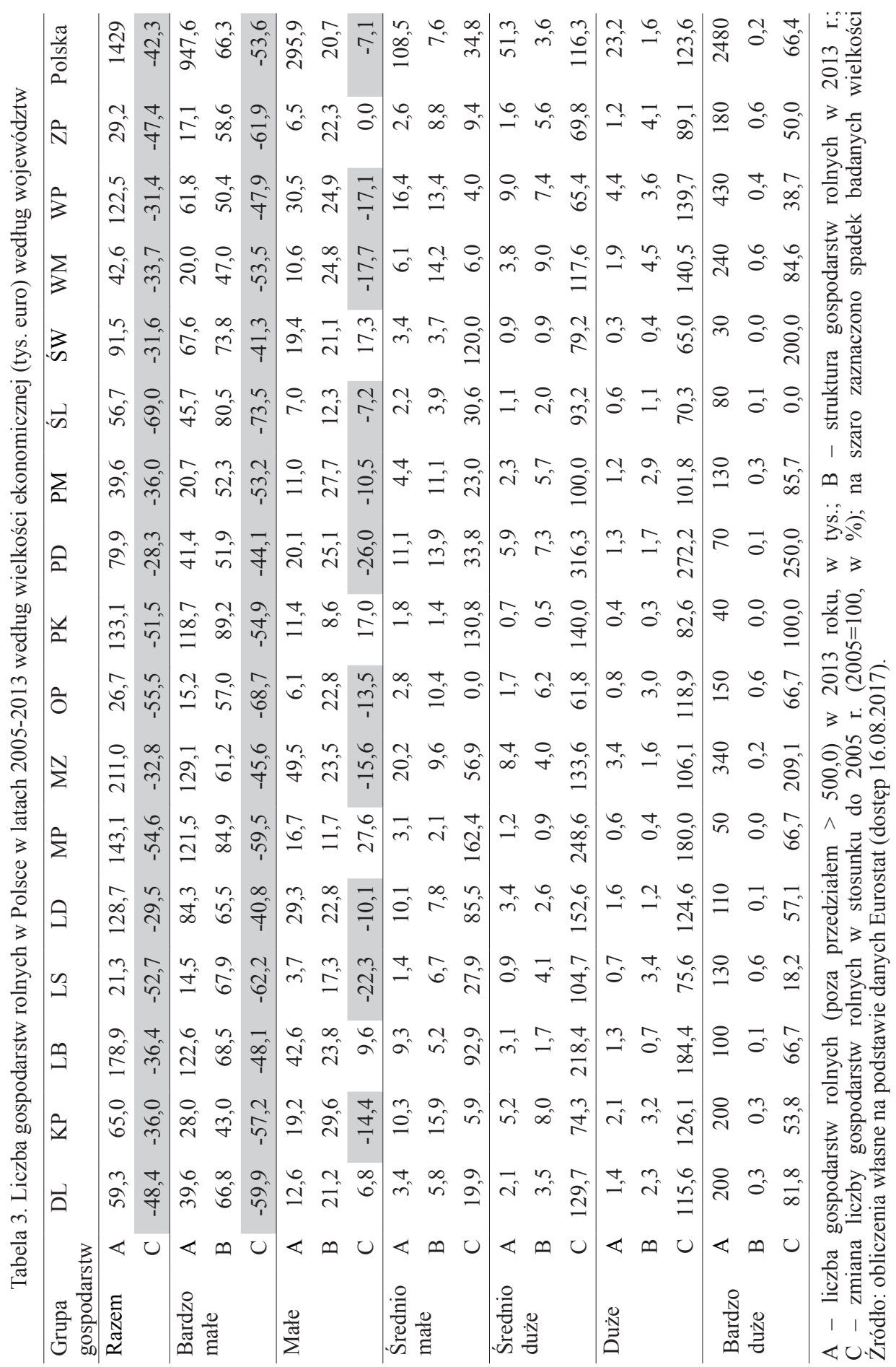


Tabela 4. Miary charakteryzujące zróżnicowanie i miary struktury ekonomicznej gospodarstw rolnych w Polsce w ujęciu regionalnym w latach 2005-2013

\begin{tabular}{|c|c|c|c|c|c|}
\hline \multirow[t]{2}{*}{ Województwo } & \multicolumn{3}{|c|}{$\begin{array}{l}\text { Stopień intensywności zmian } \\
\text { strukturalnych (wzór 7.) }\end{array}$} & \multirow{2}{*}{$\begin{array}{l}\text { Przeciętna } \\
\text { średniookresowa } \\
\text { prędkość zmian } \\
\text { (wzór 8.) }\end{array}$} & \multirow{2}{*}{$\begin{array}{c}\text { Zróżnicowanie } \\
\text { struktury } \\
v_{2013,2005} \\
\text { (wzór 7.) }\end{array}$} \\
\hline & $v_{2007,2005}$ & $v_{2010,2007}$ & $v_{2013,2010}$ & & \\
\hline wielkopolskie & 0,0144 & 0,1398 & 0,0316 & 0,0620 & 0,1592 \\
\hline dolnośląskie & 0,0085 & 0,1427 & 0,0404 & 0,0638 & 0,1901 \\
\hline kujawsko-pomorskie & 0,0073 & 0,1773 & 0,0416 & 0,0754 & 0,2129 \\
\hline lubelskie & 0,0085 & 0,1040 & 0,0550 & 0,0558 & 0,1544 \\
\hline lubuskie & 0,0171 & 0,1545 & 0,0329 & 0,0682 & 0,1699 \\
\hline łódzkie & 0,0076 & 0,1026 & 0,0375 & 0,0492 & 0,1252 \\
\hline małopolskie & 0,0075 & 0,0673 & 0,0291 & 0,0346 & 0,1039 \\
\hline mazowieckie & 0,0096 & 0,1023 & 0,0473 & 0,0531 & 0,1432 \\
\hline opolskie & 0,0148 & 0,2232 & 0,0326 & 0,0902 & 0,2414 \\
\hline podkarpackie & 0,0047 & 0,0515 & 0,0201 & 0,0254 & 0,0679 \\
\hline podlaskie & 0,0150 & 0,0951 & 0,0525 & 0,0542 & 0,1472 \\
\hline pomorskie & 0,0172 & 0,1541 & 0,0379 & 0,0697 & 0,1928 \\
\hline śląskie & 0,0176 & 0,1015 & 0,0198 & 0,0463 & 0,1388 \\
\hline świętokrzyskie & 0,0020 & 0,0876 & 0,0356 & 0,0417 & 0,1219 \\
\hline warmińsko-mazurskie & 0,0115 & 0,1689 & 0,0502 & 0,0769 & 0,1997 \\
\hline zachodniopomorskie & 0,0481 & 0,1559 & 0,0289 & 0,0776 & 0,2236 \\
\hline
\end{tabular}

Źródło: obliczenia własne na podstawie danych Eurostatu (dostęp 16.08.2017).

uwzględniania gospodarstw rolnych w statystykach publicznych ${ }^{7}$ (tab. 4.). Mając jednak na uwadze te same kryteria zaliczania gospodarstw rolnych do badań, większą intensywność zmian we wszystkich województwach zaobserwowano w latach 2010-2013 niż 2005-2007, co mogło być spowodowane dłuższym czasem funkcjonowania w strukturach wspólnej polityki rolnej.

\section{OCENA UPODABNIANIA SIE STRUKTUR I OPÓŹNIEŃ W ROZWOJU STRUKTURALNYM}

Na początku badanego okresu (2005) największą odległość (dystans strukturalny) zaobserwowano między województwem-wzorcem (wielkopolskim) a grupą województw o najniższym poziomie rozwoju rolnictwa - podkarpackim, małopolskim, śląskim i świętokrzyskim. Wymienione województwa były także tymi, dla których odległość ta była największa również w 2013 roku. Jednocześnie w okresie tym zaobserwowano wzrost

$7 \quad$ W związku z nieuwzględnieniem w badaniach struktury gospodarstw rolnych z 2010 r. w części gospodarstw najmniejszych obszarowo, z reguły o najmniejszej wielkości ekonomicznej, zmiany udziałów gospodarstw bardzo małych (do 7,9 tys. euro SO) były znaczące, co znalazło odzwierciedlenie w miarach intensywności zmian strukturalnych. 
Tabela 5. Miary oceny opóźnień w rozwoju strukturalnym dla poszczególnych województw w Polsce

\begin{tabular}{|c|c|c|c|c|c|}
\hline Województwo & $\begin{array}{c}\text { Odległość } \\
\text { od wzorca } \\
\text { (dystans } \\
\text { strukturalny) } \\
2005 \\
\text { (wzór 11.) }\end{array}$ & $\begin{array}{c}\text { Odległość } \\
\text { od wzorca } \\
\text { (dystans } \\
\text { strukturalny) } \\
2013 \\
\text { (wzór 11.) }\end{array}$ & $\begin{array}{c}\text { Stopień } \\
\text { monotoniczności } \\
\text { (wzór 9.) }\end{array}$ & $\begin{array}{l}\text { Współczynnik } \\
\text { zakłóceń } \\
\text { (wzór 10.) }\end{array}$ & $\begin{array}{c}\text { Dystans } \\
\text { czasowy } \\
\text { (wzór 12.) }\end{array}$ \\
\hline wielkopolskie & 0,0000 & 0,0000 & 0,856 & $\mathrm{x}$ & $\mathrm{x}$ \\
\hline dolnośląskie & 0,1946 & 0,1637 & 0,993 & 1,007 & 7,75 \\
\hline kujawsko-pomorskie & 0,0234 & 0,0788 & 0,941 & 1,062 & 3,33 \\
\hline lubelskie & 0,1758 & 0,1806 & 0,922 & 1,085 & 10,53 \\
\hline lubuskie & 0,1860 & 0,1771 & 0,831 & 1,204 & 9,38 \\
\hline łódzkie & 0,1164 & 0,1504 & 0,848 & 1,180 & 10,81 \\
\hline małopolskie & 0,2893 & 0,3446 & 1,000 & 1,000 & 29,85 \\
\hline mazowieckie & 0,0916 & 0,1076 & 0,900 & 1,112 & 6,76 \\
\hline opolskie & 0,1481 & 0,0680 & 0,892 & 1,121 & 2,54 \\
\hline podkarpackie & 0,2959 & 0,3872 & 0,890 & 1,124 & 51,32 \\
\hline podlaskie & 0,0401 & 0,0222 & 0,905 & 1,105 & 1,36 \\
\hline pomorskie & 0,0519 & 0,0468 & 0,922 & 1,085 & 2,18 \\
\hline śląskie & 0,2802 & 0,3006 & 0,999 & 1,001 & 19,49 \\
\hline świętokrzyskie & 0,1963 & 0,2336 & 0,974 & 1,027 & 17,25 \\
\hline $\begin{array}{l}\text { warmińsko- } \\
\text { mazurskie }\end{array}$ & 0,0092 & 0,0352 & 0,866 & 1,155 & 1,59 \\
\hline zachodniopomorskie & 0,1478 & 0,0899 & 0,960 & 1,041 & 3,62 \\
\hline
\end{tabular}

$\mathrm{x}$ - wypełnienie pozycji jest niecelowe

Źródło: obliczenia własne na podstawie danych Eurostatu (dostęp 16.08.2017).

badanej wielkości, wskazujący na powiększanie się dystansu dzielącego strukturę ekonomiczną gospodarstw z tych województw a województwem wielkopolskim (tab. 5.). Potwierdzają to również badania z wykorzystaniem innych metod statystycznej analizy strukturalnej [Rzeszutko 2016].

Z drugiej strony, wśród województw, które od wzorca dzieliła najmniejsza odległość w 2005 r., znalazły się m.in.: warmińsko-mazurskie, kujawsko-pomorskie, podlaskie czy pomorskie - głównie województwa o wysokim i średnim poziomie rozwoju rolnictwa. W badanym okresie z reguły zmniejszyły one dystans strukturalny dzielący je od województwa-wzorca (tab. 5.) . $^{8}$

Obserwowane w poszczególnych województwach zmiany strukturalne charakteryzowały się względnie wysokim stopniem monotoniczności, jednak analiza ciągów wskaźników monotoniczności dla badanego okresu wskazała, że struktury ekonomiczne

$8 \quad$ W województwach warmińsko-mazurskim i kujawsko-pomorskim dystans ten w stosunku do dystansu z 2005 r. nieco się powiększył, lecz nadal były to województwa najbardziej zbliżone strukturą ekonomiczną gospodarstw rolnych do województwa-wzorca. 
gospodarstw rolnych nie ewoluowały ściśle monotonicznie. Pojawiają się pewne zakłócenia. Wyznaczenie dystansu czasowego dzielącego struktury ekonomiczne gospodarstw rolnych z badanych województw względem struktury wzorcowej w województwie wielkopolskim z 2013 r. wymaga zatem wyznaczenia współczynnika zakłóceń (tab. 5.).

W wyniku przeprowadzonych badań zaobserwowano, że dystans czasowy - opóźnienie w rozwoju strukturalnym gospodarstw rolnych było tym większe, im niższy był poziom rozwoju gospodarstw rolnych w danym województwie ${ }^{9}$. Najdłuższy dystans czasowy względem województwa wielkopolskiego w ostatnim roku badanego okresu (2013) odnotowano dla gospodarstw rolnych z południowo-wschodnich województw Polski: podkarpackiego, małopolskiego, śląskiego oraz świętokrzyskiego. Opóźnienie czasowe względem struktury ekonomicznej gospodarstw rolnych z województwa wielkopolskiego z 2013 roku wynosiło od około 20 do nawet 50 lat w przypadku województwa podkarpackiego (tab. 5.).

$\mathrm{Z}$ drugiej strony, najmniejszy dystans czasowy (od około ponad roku do prawie 4 lat) cechował gospodarstwa rolne głównie z północnych województw Polski, tj. podlaskiego, warmińsko-mazurskiego, pomorskiego i zachodniopomorskiego oraz z województwa opolskiego. Już w 2013 roku struktura ekonomiczna gospodarstw rolnych w wymienionych województwach była bardzo zbliżona do struktury w województwie wielkopolskim.

\section{PODSUMOWANIE I WNIOSKI}

Przeprowadzone badania skłaniają do następujących wniosków:

1. Zmniejszenie liczby gospodarstw o najmniejszej wielkości ekonomicznej wraz ze wzrostem liczby gospodarstw o większej sile (powyżej 25 tys. euro SO), zarówno w skali kraju, jak i województw, jest zjawiskiem pozytywnym, gdyż prowadzi do wzrostu liczby gospodarstw zdolnych do odtwarzania potencjału produkcyjnego. Nadal jednak zróżnicowanie regionalne struktury ekonomicznej gospodarstw rolnych jest bardzo duże.

2. Województwa o wysokim i średnim poziomie rozwoju rolnictwa charakteryzują się szybszym średnim tempem (natężeniem) zmian struktury ekonomicznej gospodarstw rolnych. Wykazują one także największe zróżnicowanie struktur względem początku badanego okresu, co oznacza, że w strukturach ekonomicznych gospodarstw z tych województw dokonały się relatywnie największe zmiany.

3. Największy dystans strukturalny zarówno na początku (2005), jak i na końcu (2013) badanego okresu zaobserwowano między województwami o bardzo niskim i niskim poziomie rozwoju rolnictwa (województwa południowo-wschodniej Polski) a województwem o najwyższym poziomie rozwoju rolnictwa - wielkopolskim, w którym strukturę ekonomiczną gospodarstw rolnych uznano za wzorcową. Jednocześnie dystans ten widocznie się powiększa, co wskazuje na pogłębianie nierówności w rozwoju strukturalnym rolnictwa w Polsce w ujęciu regionalnym.

4. Najmniejszy dystans strukturalny odnotowano w stosunku do grupy województw o wysokim i średnim poziomie rozwoju rolnictwa. W badanym okresie dystans ten dodatkowo zmniejszył się.

5. Wielkość opóźnienia w rozwoju strukturalnym (dystans czasowy) jest odwrotnie pro-

\footnotetext{
$9 \quad$ Współczynnik korelacji między poziomem rozwoju gospodarstw rolnych a opóźnieniem w rozwoju struk-
} turalnym wyniósł 0,744 . 
porcjonalna do poziomu rozwoju rolnictwa - im wyższy poziom tego rozwoju, tym opóźnienie jest mniejsze. Największe opóźnienie, wynoszące 20-50 lat, charakteryzuje gospodarstwa rolne z województw południowo-wschodnich, w szczególności podkarpackiego, małopolskiego, śląskiego i świętokrzyskiego. Nie oznacza to, że struktura ekonomiczna gospodarstw rolnych z tych województw zrówna się po tym czasie ze strukturą obserwowaną w województwie wielkopolskim. Oznacza to co najwyżej, że po takim okresie przyjmie ona kształt struktury z Wielkopolski z 2013 roku, pod warunkiem zachowania stałego kierunku zmian i kształtowania się prędkości obu struktur na zbliżonym poziomie.

\section{LITERATURA}

Bański Jerzy, 2007: Geografia rolnictwa Polski, PWE, Warszawa.

Bożek Jadwiga, 2012: Kierunki zmian struktury agrarnej województw wedtug grup typologicznych (prognoza do roku 2020), Metody ilościowe w badaniach ekonomicznych, t. XIII/1, red. Bolesław Borkowski, Karol Kukuła, Katedra Ekonometrii i Statystyki SGGW, Warszawa, s. 58-68.

Charakterystyka gospodarstw rolnych w 2005 roku, GUS, Warszawa, 2006.

Czyżewski Andrzej, Sebastian Stępień, 2014: Fundusze unijne dla Polski i polskiego sektora rolnego w perspektywie 2014-2020, Polityki Europejskie, „Finanse i Marketing”, nr 11(60), s. 34-45.

Ezeala-Harrison Fidelis, 1996: Economic development: theory and policy applications, Praeger Publishers, Westport.

Farm Structure Survey 2010, Survey on agricultural production methods 2010, National Methodological Report, Member State: Poland, 2012: Central Statistical Office, Agriculture Division, Warsaw.

Głębocki Benicjusz (red.), 2014: Zróżnicowanie przestrzenne rolnictwa, Powszechny Spis Rolny 2010, GUS, Warszawa, s. 488.

Goraj Lech, Stanisław Mańko, Dariusz Osuch, Renata Płonka, 2011: Wyniki standardowe uzyskane przez gospodarstwa rolne uczestniczace w Polskim FADN w 2010 roku, Część 1. Wyniki Standardowe, IERGiŻ-PIB, Warszawa.

Karwat-Woźniak Bożena, 2016: Strukturalne uwarunkowania konkurencyjności polskiego rolnictwa, „Marketing i Rynek”, nr 10, s. 230-245.

Kowalczyk Stanisław, 1991: Rolnictwo: rozwój-struktura, Wydawnictwo Spółdzielcze, Warszawa.

Kukuła Karol, 1996: Statystyczne metody analizy struktur ekonomicznych, Wydawnictwo Edukacyjne, Kraków, s. 166.

Kukuła Karol, 2010: Statystyczne studium struktury agrarnej w Polsce, PWN, Warszawa.

Kulawik Jacek, 1997: Rozwój finansowy a wzrost i rozwój ekonomiczny w rolnictwie, IERiGŻ-PIB, Warszawa.

Małuszyńska Ewa, 1993: Regionalne zróżnicowanie zmienności struktur gospodarczych, „Zeszyty Naukowe. Seria II, Prace Habilitacyjne”, z. 132, Wydawnictwo AE w Poznaniu, Poznań.

Michna Waldemar, 2011: Wizja pożądanego rozwoju rolnictwa do 2020 roku, [w] Procesy zachodzace $w$ rolnictwie polskim $w$ latach 1990-2010, projekcje na rok 2013 i pożadana wizja rolnictwa w 2020 roku-zagadnienia wybrane, Raport 21, IERiGŻ-PIB, Warszawa, s. 33-51.

Onufer Aneta, 2009: Zmiany strukturalne - zjawisko i jego pomiar, [w] Instytucjonalne czynniki rozwoju gospodarczego pierwszej dekady XXI wieku, Ekonomia, t. 17, red. Leon Olszewski, Wydawnictwo Uniwersytetu Wrocławskiego, Wrocław, s. 175-186.

Pawlak Karolina, 2014: Rzeczywista i potencjalna konkurencyjność sektora rolno-żywnościowego krajów UE, [w] Wybrane problemy konkurencyjności sektora rolno-spożywczego w Polsce $i$ Unii Europejskiej, red. Karolina Pawlak, Bożena Nosecka, Wydawnictwo IERIGŻ, Warszawa, s. 67-104.

Poczta Walenty, Arkadiusz Sadowski, Agnieszka Baer-Nawrocka, 2013: Gospodarstwa rolne w Polsce na tle gospodarstw Unii Europejskiej - wptyw WPR. Powszechny Spis Rolny 2010, GUS, Warszawa, s. 254

Przygodzka Renata, 2011: Polityka fiskalna a zmiany strukturalne polskiego rolnictwa [w] Gospodarki narodowe w procesie przemian strukturalnych, „Studia Ekonomiczne, Zeszyty Naukowe 
Wydziałowe Uniwersytetu Ekonomicznego w Katowicach", s. 142- 151.

Rozporzadzenie Parlamentu Europejskiego i Rady (WE) Nr 1166/2008 z dnia 19 listopada 2008 r., OJ L 321, z 1.12.2008.

Rzeszutko Anna, 2014a: Regionalne zróżnicowanie przemian struktury rolnictwa w Polsce w warunkach integracji z Unia Europejska, Wydawnictwo Uniwersytetu Przyrodniczego w Poznaniu, Poznań, s. 231.

Rzeszutko Anna, 2014b: Efektywność produkcyjna rolnictwa w Polsce a relacje między czynnikami produkcji, ,Journal of Agribusiness and Rural Development”, 2(32), s. 141-154.

Rzeszutko Anna 2016: Zmiany struktury ekonomicznej gospodarstw rolnych $w$ Polsce $w$ ujęciu regionalnej analizy strukturalnej, „Roczniki Ekonomii Rolnictwa i Rozwoju Obszarów Wiejskich", t. 103, z. 4, s. 32-47.

Sikorska Alina, Agnieszka Wrzochalska, Paweł Chmieliński, 2009: Wspólna Polityka Rolna a zróżnicowanie regionalne polskiego rolnictwa, [w] Przemiany strukturalne wsi i rolnictwa $w$ wybranych krajach europejskich, Raport 128, IERiGŻ-PIB, Warszawa, s. 9-29.

Woś Augustyn, 2004: W poszukiwaniu modelu rozwoju polskiego rolnictwa, IERiGŻ-PIB, Warszawa. Wilkin Jerzy, 2012: Wieś i rolnictwo w strukturach współczesnej Polski, [w] Uwarunkowania ekonomiczne polityki rozwoju polskiej wsi i rolnictwa, red. Mirosław Drygas, Katarzyna Zawalińska, IRWIR PAN, Warszawa, s. 19-39.

Wysocki Feliks, 2010: Metody taksonomiczne w rozpoznawaniu typów ekonomicznych rolnictwa $i$ obszarów wiejskich, Wydawnictwo Uniwersytetu Przyrodniczego w Poznaniu, Poznań.

Zegar Józef Stanisław, 2009: Struktura polskiego rolnictwa rodzinnego pod koniec pierwszej dekady XXI wieku, IERiGŻ-PIB, Warszawa.

\section{Anna Rzeszutko}

\section{THE CHANGES IN THE ECONOMIC STRUCTURE OF POLISH FARMS - ESTIMATION OF THE STRUCTURAL DEVELOPMENT GAP}

\section{Summary}

The aim of the paper was to estimate the structural development gap in Polish agriculture at the regional level (provinces) and to assess the unification process of economic structure of farms. The economic structure of farms was determined on the basis of the value of Standard Output (SO). The research was conducted based on EUROSTAT data for the period 2005-2013. In order to estimate the structural development gap in agriculture the procedure proposed by Karol Kukuła was used. This procedure is based on the regional structural analysis methods and requires the indication of the exemplar structure - the standard province). The standard province was identified with the use of Hellwig synthetic measure. It was found that the biggest structural development gap of farms was observed in the southern-east region of Poland. At the same time, in provinces from this region of Poland the structural development gap compared to wielkopolskie province served as a standard province increased in the years 2005-2013.

Adres do korespondencji: Dr Anna Rzeszutko

Uniwersytet Przyrodniczy w Poznaniu Katedra Ekonomii i Polityki Gospodarczej w Agrobiznesie ul. Wojska Polskiego 28, 60-637 Poznań e-mail: rzeszutko@up.poznan.pl 